\title{
MANTLE OXYGEN FUGACITY AND DIAMOND FORMATION
}

\author{
Catherine A. McCammon ${ }^{1}$ and Maya G. Kopylova ${ }^{2}$ \\ ${ }^{I}$ Bayerisches Geoinstitut, Germany; ${ }^{2}$ University of British Columbia, Canada
}

\section{INTRODUCTION}

Oxygen fugacity is an important, although elusive, parameter of the mantle. It can affect subsolidus and supersolidus phase relations as well as determine the presence and speciation of a fluid phase; hence it has a large influence on diamond formation. There are at least three distinct methods that have been used to estimate mantle oxygen fugacity: (a) electrochemical methods (intrinsic oxygen fugacity); (b) calibration of $\mathrm{Fe}^{3+} / \mathrm{Fe}^{2+}$ ratios in quenched silicate melts; and (3) mineral oxybarometers, particularly olivineorthopyroxene-spinel. Efforts over the past twenty years have produced much data concerning upper mantle oxygen fugacity, and although agreement is not universal, a relatively consistent picture is emerging. The oxidation state measured for lithospheric upper mantle is heterogeneous on a scale of at least four log units, where trends in oxygen fugacity have been noted to occur with metasomatism (e.g. McCammon et al., 2001), partial melting (e.g. Bryndzia and Wood, 1990; Kadik, 1997) and tectonic environment (e.g. Wood et al., 1990; Ballhaus, 1993). Values range from roughly FMQ to FMQ-1 for suboceanic abyssal peridotites and xenoliths from zones of continental extension (Wood et al., 1990), while more oxidised values have been recorded for xenoliths from regions of recent or active subduction (Parkinson and Arculus, 1999).

The calibration of an oxybarometer for the olivineorthopyroxene-garnet assemblage (Gudmundsson and Wood, 1995) enables direct determinations of oxygen fugacity to be extended to depths of at least $200 \mathrm{~km}$. Although calculation of $\mathrm{Fe}^{3+} / \Sigma \mathrm{Fe}$ in spinel is marginally viable based on stoichiometry assumptions using electron microprobe data, the errors associated with the calculation for garnet are generally too large to be petrologically useful (Canil and O'Neill, 1996; Sobolev et al., 1999). Accurate determinations of $\mathrm{Fe}^{3+} / \Sigma \mathrm{Fe}$ in garnet require a technique such as Mössbauer spectroscopy, which has restricted the number of such investigations. Recent data from Finland (Woodland and Peltonen, 1999) and Lesotho (Woodland, 2001) show a general decrease in oxygen fugacity with depth, which supports suggestions based on the reduced volume of $\mathrm{Fe}^{3+}$ in garnet (e.g. Wood et al., 1990; Ballhaus, 1995). The addition of a new dataset focusing

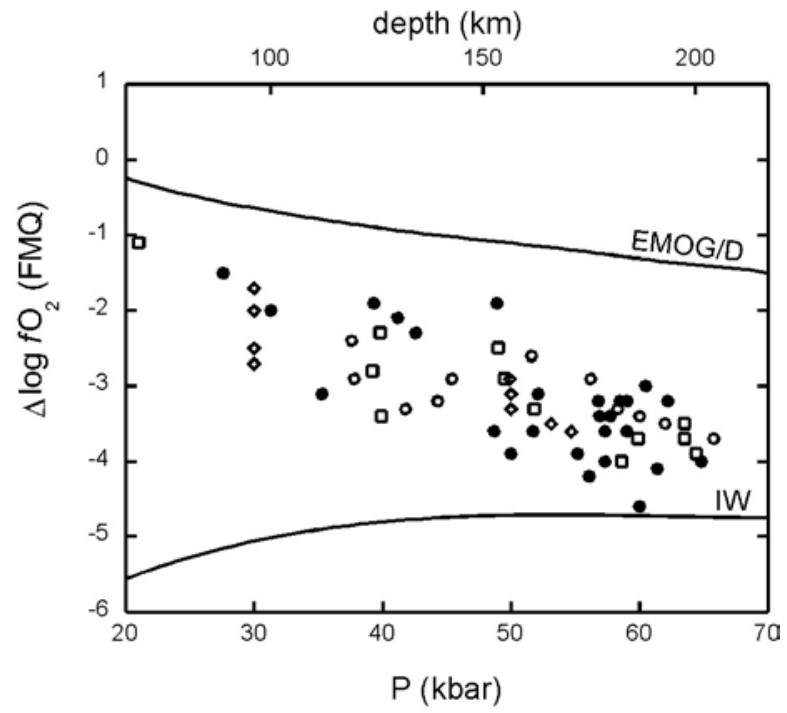

Figure 1: Variation of oxygen fugacity (relative to FMQ) with pressure for garnet-bearing peridotites. Symbols refer to the present data from the Slave craton (solid circles); Fennoscandia (open diamonds; Woodland and Peltonen, 1999); and South Africa (open circles and open squares; McCammon et al., 2001 based on Mössbauer data of Luth et al., 1990 and Canil and O'Neill, 1996, respectively). Buffer curves for IW (Ballhaus et al., 1991) and EMOG/D (Eggler and Baker, 1982) are given for temperatures corresponding to a model steady-state conductive geotherm for the Slave craton (Kopylova et al., 1999).

on the Slave region of northern Canada (Kopylova and McCammon, this volume) provides a more global view of oxygen fugacity in the deep lithosphere, and motivates a re-examination of the influence of oxygen fugacity on diamond formation, particularly with regard to observables such as carbon isotopic composition.

\section{DATA COLLECTION AND RESULTS}

\section{GARNET PERIDOTITES}

We determined the oxidation state of iron in garnetbearing xenoliths from the Jericho and Gahcho Kue kimberlite pipes located in the northern and southeastern parts of the Slave craton (Canada) using Mössbauer spectroscopy, and used the olivineorthopyroxene-garnet oxybarometer (Gudmundsson and Wood, 1995) in conjunction with thermobarometry to construct an oxygen fugacity profile through the 
Slave cratonic mantle (Fig. 1) (see also Kopylova and McCammon, this volume). There is a general trend with depth to more reduced values of oxygen fugacity, reaching nearly to the iron-wüstite buffer for the deepest samples. Results from South Africa and Finland show similar trends, and Woodland (2001) reported oxygen fugacites from Lesotho samples that range from FMQ-2 to FMQ-4 over the depth interval 80-225 km.

The data plotted in Fig. 1 represent a range of rock types, including garnet harzburgites, garnet lherzolites, pyroxenites and megacrysts. Also, equilibration temperatures vary with geographic location, where samples from Canada are generally cooler than those from Finland and South Africa for a given depth, reflecting the different thermal structure of the mantle beneath the different cratons (e.g. Kopylova et al., 1999). Such variations cause a degree of data scatter, but also serve to illustrate the generally reduced nature of such deep samples, regardless of their chemistry or magmatic history. Note that effects due to subsequent metasomatism or other alteration are probably not reflected in the data set, since garnet samples for study using Mössbauer spectroscopy were carefully selected to avoid such alteration.

\section{PeRidotitic InClusions in diamond}

Oxygen fugacity determinations from peridotitic inclusions in diamond are consistent with the data shown in Fig. 1. Results have been reported based on the olivine-orthopyroxene-spinel oxybarometer for a number of diamond localities: Dokolwayo (Kaapvaal craton) (Daniels and Gurney, 1991); River Ranch and Venetia (Limpopo mobile belt) (Kopylova et al., 1997; Deines et al., 2001), Mir (Yakutian craton; Simakov, 1998 from data of Sobolev et al., 1976) and Argyle (North Australian craton; Kadik, 1997 from data of Jaques et al., 1991). All data show oxygen fugacities that range from FMQ-3 to FMQ-5 at an assumed pressure of $50 \mathrm{kbar}$.

\section{ECLOGITES AND ECLOGITIC INCLUSIONS}

There are limited data for oxygen fugacity estimates of eclogitic xenoliths and eclogitic inclusions in diamond, because the bimineralic eclogite system lacks sufficient constraints to allow direct determination of oxygen fugacity using mineral oxybarometers. Results are available from electrochemical measurements of kyanite crystals from diamond-bearing high-alumina eclogites from Udachnaya (Yakutian craton; Kadik et al., 1993), and show predominantly reduced values with a single more oxidised result (Fig. 2). Evidence that

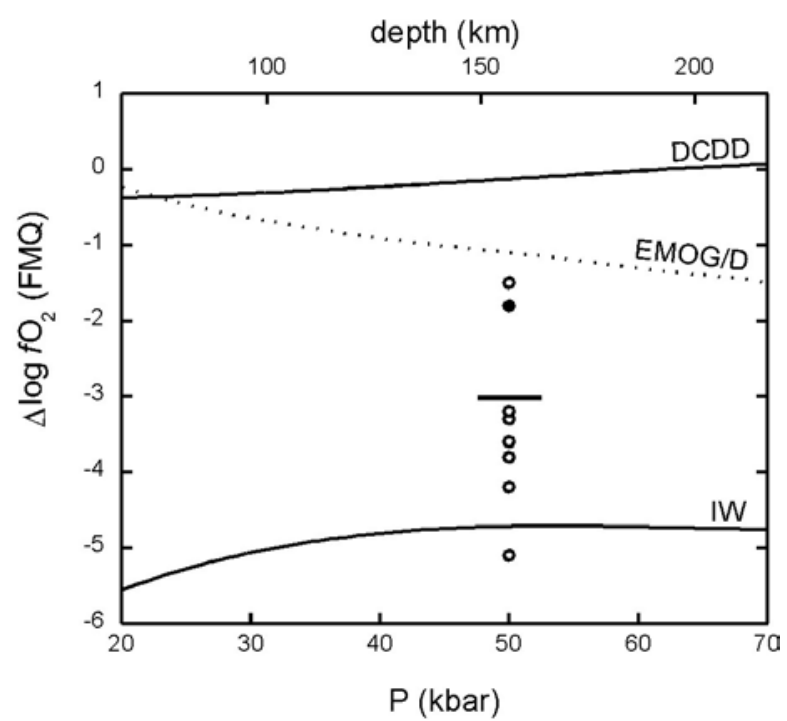

Figure 2: Variation of oxygen fugacity (relative to FMQ) with pressure for eclogite xenoliths (open circles; Kadik, 1997) and eclogitic inclusions in diamonds (solid circle; Simakov, 2002 based on Mössbauer data of McCammon et al., 1998). Buffer curves for IW (Ballhaus et al., 1991), DCDD (Luth, 1993) and EMOG/D (Eggler and Baker, 1982) are given for temperatures corresponding to a model steadystate conductive geotherm for the Slave craton (Kopylova et al., 1999). The horizontal line indicates the point of zero carbon isotopic fractionation at $50 \mathrm{kbar}$ and $1200^{\circ} \mathrm{C}$ (Deines, 1980).

supports the credibility of the data comes from a similar investigation of Udachnaya peridotites (Kadik et al., 1990), where values of FMQ-3 to FMQ-6 were obtained at $50 \mathrm{kbar}$, more or less consistent with other peridotite data in Fig. 1. Although the garnetclinopyroxene oxybarometer cannot provide exact oxygen fugacities since silica activity is unconstrained, a formulation by Simakov (2002) gave a relatively oxidised value for eclogitic inclusions in diamonds from George Creek (off-craton mobile belt, ColoradoWyoming Province) based on Mössbauer data of McCammon et al. (1998) (presumably silica was assumed to be saturated, which would give a maximum value for oxygen fugacity). Other indications of relatively oxidising conditions come from observations of fluid inclusions in eclogitic diamonds, where oxidised species such as $\mathrm{CO}_{2}$, carbonate and water have been identified (reviewed by Navon, 1999).

The potential for eclogitic diamonds to form in more oxidising environments was recognised by Luth (1993), who examined the reaction of dolomite + coesite to form diopside + diamond + oxygen (DCDD), which defines the most oxidising conditions under which diamond can exist in eclogite. As seen in Fig. 2, this 
reaction lies several log units above the enstatitemagnesite-olivine-diamond-oxygen (EMOD) equilibrium, which defines the upper stability for diamond in harzburgite (Eggler and Baker, 1982).

Although more work is needed to determine oxygen fugacity for the eclogite paragenesis, existing evidence suggests that there is a wider range of redox conditions recorded for eclogite xenoliths and diamonds compared to the peridotite paragenesis.

\section{DISCUSSION}

\section{FLUIDS AND MANTLE REDOX CONTROL}

The general picture of the Archean cratonic mantle derived from oxygen fugacity determinations of garnetbearing xenoliths is the reduction in oxygen fugacity with depth in deep garnet-bearing lithosphere. Local heterogeneities due to processes such as subduction or magmatism probably exist, as reflected by the large range of oxygen fugacities recorded by mantle samples from different environments, but the overall picture is of a general decrease in oxygen fugacity with depth.

Such behaviour strongly suggests that mantle oxygen fugacity in cratonic peridotitic lithosphere is highly influenced (or even controlled) by iron equilibria. The relatively oxidised nature of the upper garnet-bearning lithosphere has been attributed to the high concentration of $\mathrm{Fe}^{3+}$ in modally minor phases such as spinel and clinopyroxene due to the limited ability of olivine to incorporate $\mathrm{Fe}^{3+}$ (e.g. O'Neill et al., 1993), and the reduction in oxygen fugacity with depth can be attributed to the reduced volume of $\mathrm{Fe}^{3+}$ in garnet (Wood et al., 1990; Ballhaus, 1995). The composition of fluids in equilibrium with peridotitic mantle is therefore likely dominated by $\mathrm{CH}_{4}$ (e.g. Woermann and Rosenhauer, 1985), and fluids infiltrating the region would be subject to either oxidation or reduction, depending on their initial oxygen fugacity and relative concentration.

In contrast to the behaviour of peridotitic mantle, the oxygen fugacity in eclogitic mantle may have fewer controls. The bimineralic eclogite assemblage has an additional degree of freedom, so is more likely to be influenced by the composition of incoming fluids.

\section{CARBON ISOTOPE FRACTIONATION}

Carbon isotopic composition patterns observed in mantle xenoliths and diamonds have puzzled scientists for decades (see Navon, 1999 and Deines, 2002 for a

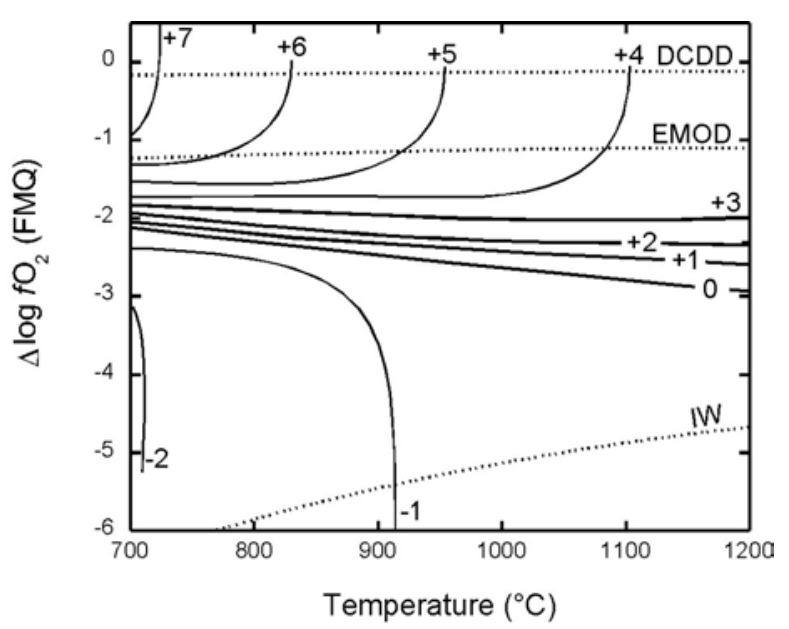

Figure 3: Carbon isotope fractionation (1000 $\left.\ln \alpha_{\mathrm{V}-\mathrm{D}}\right)$ between a vapour phase and diamond in the system C-H-O at $50 \mathrm{kbar}$ from Deines (1980). The size of the isotope effect (in permil) has been indicated along the curves. Oxygen fugacities were recalculated relative to FMQ (formulation of Ballhaus et al., 1991), and buffer curves corresponding to IW (Ballhaus et al., 1991), DCDD (Luth, 1993) and EMOG/D (Eggler and Baker, 1982) are indicated.

review). The large range of carbon isotopic signatures in eclogitic diamonds ( +3 to $-35 \%$ ) compared to those from peridotitic diamonds (generally between +1 and $-10 \%$ with a mean of $-4.6 \%$ ) has been attributed to various processes, including biogenic input through subduction, primitive mantle heterogeneity, and hightemperature fractionation of mantle carbon. While a detailed discussion of this topic is beyond the scope of this paper, it is relevant in the context of this work to examine the effect of oxygen fugacity on carbon isotope fractionation.

Deines (1980) calculated the carbon isotope fractionation between vapour and diamond as a function of pressure, temperature and oxygen fugacity, and demonstrated that there is a large region in $\mathrm{fO}_{2}-T$ space at $50 \mathrm{kbar}$ where fractionation is negligible. We have recalculated the fractionation curves relative to the FMQ buffer formulation of Ballhaus et al. (1991), which enables a comparison of oxygen fugacity values from the present study. Fig. 3 supports the observation of Deines et al. (2001) for Venetia diamonds that nearly all values for peridotitic xenoliths and diamond inclusions fall within the region of negligible fractionation. The behaviour for eclogitic parageneses is different, however, since while some values fall below FMQ-3, which defines the zero fractionation limit at $50 \mathrm{kbar}$ and $1200^{\circ} \mathrm{C}$ (Fig. 2), the presence of more oxidised values recorded from eclogitic samples 
implies the possibility of greater carbon isotope fractionation in the eclogitic system.

\section{SCENARIOS FOR DIAMOND FORMATION}

The stability of diamond in the eclogite system at higher oxygen fugacities compared to the peridotite system may provide a mechanism to account for observed carbon isotopic compositions. As illustrated in Fig. 3, diamonds formed at higher oxygen fugacities experience a higher carbon isotope fractionation. In a closed system, such fractionation factors are not sufficiently large to generate the observed $\delta^{13} \mathrm{C}$ distributions (e.g. Deines, 1980), but open-system degassing of $\mathrm{CO}_{2}$ (Rayleigh fractionation) could easily produce large variations. Such a process was proposed by Cartigny et al. (1998) to account for $\delta^{13} \mathrm{C}$ values in eclogitic diamonds from Jwaneng, since variations in $\delta^{15} \mathrm{~N}$ argued against a substantial biogenic or recycled contribution.

If oxygen fugacity were a significant factor in carbon fractionation during diamond formation, a relation should be observed between diamond $\delta^{13} \mathrm{C}$ and the oxygen fugacity recorded by the mineral inclusions. In a study of diamonds and their inclusions from Venetia, Deines et al. (2001) found no obvious relationship between carbon isotopic composition, oxygen fugacity and temperature in peridotitic diamonds. They were unable to measure oxygen fugacity for the eclogitic diamonds, however, and did note that the peridotitic diamond with the lowest $\delta^{13} \mathrm{C}$ content (-18\%o, compared to a mean near $-4.6 \%$ ) was also the diamond whose inclusions recorded one of the highest oxygen fugacities.

It is clear that further data is needed to assess the role of oxygen fugacity in diamond formation. In particular, correlations of observables such as carbon and nitrogen isotopes from diamonds and the major and trace element chemistry of their inclusions are needed, combined with luminescence measurements to identify variations with different growth events. There is also an urgent need for detailed studies of $\mathrm{Fe}^{3+}$ behaviour with oxygen fugacity in the eclogite system to complement those studies existing for peridotite, since differences in $\mathrm{Fe}^{3+}$ behaviour may be crucial to understanding the nature of diamond formation. Various studies have already documented the complexity of diamond and inclusion chemistry, and it is possible that more than one process contributes to observed variations in carbon isotopic compositions.

\section{SUMMARY}

We have compiled a worldwide dataset of oxygen fugacity for the deep cratonic lithosphere to $200 \mathrm{~km}$ based on new data, existing data and recalculations of literature analyses using the Gudmundsson and Wood (1995) oxybarometer. The global picture shows a significant decrease in oxygen fugacity with depth through the cratonic garnet-bearing peridotitic mantle, fully consistent with the reduced volume of $\mathrm{Fe}^{3+}$ in garnet. Results from peridotitic inclusions in diamonds show a similar trend, suggesting that peridotitic diamonds formed under relatively reducing conditions. In contrast, examination of the limited data available for eclogitic xenoliths and eclogitic diamond inclusions suggests that a greater range of redox conditions existed during the formation of eclogitic diamonds. Combined with the dependence of carbon fractionation on oxygen fugacity, these observations suggest a scenario for diamond formation involving Rayleigh fractionation that could account for observed variations in carbon isotopic composition. Existing evidence provides tantalising hints of such a process, but further progress in this area requires more comprehensive studies of diamonds and their inclusions.

\section{REFERENCES}

Ballhaus, C., 1993. Redox states of lithospheric and asthenospheric upper mantle. Contrib. Mineral. Petrol., 114: 331-348.

Ballhaus, C., 1995. Is the upper mantle metal-saturated? Earth Planet. Sci. Lett., 132: 75-86.

Ballhaus, C., Berry, R.F. and Green, D.H., 1991. High pressure experimental calibration of the olivineorthopyroxene-spinel oxygen barometer: implications for the oxidation state of the upper mantle. Contrib. Mineral. Petrol., 107: 27-40.

Bryndzia, L.T. and Wood, B.J., 1990. Oxygen thermobarometry of abyssal spinel peridotites: the redox state and $\mathrm{C}-\mathrm{O}-\mathrm{H}$ volatile composition of the Earth's sub-oceanic upper mantle. Amer. J. Sci., 290: 1093-1116.

Canil, D. and O'Neill, H.S.C., 1996. Distribution of ferric iron in some upper-mantle assemblages. J. Petrol., 37: 609635.

Cartigny, P., Harris, J.W. and Javoy, M., 1998. Eclogitic diamond formation at Jwaneng: No room for a recycled component. Science, 280: 1421-1424.

Daniels, L.R.M. and Gurney, J.J., 1991. Oxygen fugacity constraints on the southern African lithosphere. Contrib. Mineral. Petrol., 108: 154-161.

Deines, P., 1980. The carbon isotopic composition of diamonds: Relationship to diamond shape, color, occurrence and vapor composition. Geochim. 
Cosmochim. Acta, 44: 943-961.

Deines, P., 2002. The carbon isotope geochemistry of mantle xenoliths. Earth Sci. Rev., 58: 247-278.

Deines, P., Viljoen, F. and Harris, J.W., 2001. Implications of the carbon isotope and mineral inclusion record for the formation of diamonds in the mantle underlying a mobile belt: Venetia, South Africa. Geochim. Cosmochim. Acta, 65: 813-838.

Eggler, D.H. and Baker, D.R., 1982. Reduced volatiles in the system C-O-H: Implications to mantle melting, fluid formation, and diamond genesis. In: S. Akimoto and M.H. Manghnani (Editors), High Pressure Research in Geophysics. Center for Academic Publications Japan, Tokyo, pp. 237-250.

Gudmundsson, G. and Wood, B.J., 1995. Experimental tests of garnet peridotite oxygen barometry. Contrib. Mineral. Petrol., 119: 56-67.

Jaques, A.L., O'Neill, H.S., Smith, C.B., Moon, J. and Chappell, B.W., 1990. Diamondiferous peridotite xenoliths from the Argyle (AK) lamproite pipe, Western Australia. Contrib. Mineral. Petrol., 104: 255276.

Kadik, A., 1997. Evolution of Earth's redox state during upwelling of carbon-bearing mantle. Phys. Earth Planet. Int., 100: 157-166.

Kadik, A., Sobolev, N.V., Zharkova, Y.V. and Pokhilenko, N.P., 1990. Redox conditions of formation of diamond-bearing peridotite xenoliths in the Udachnaya kimberlite pipe, Yakutia. Geochem. Int., 27: 41-53.

Kadik, A., Zharkova, Y.V. and Spetius, Z.V., 1993. Redox conditions during the generation of diamond-bearing kyanite eclogite in the Udachnaya kimberlite pipe, Yakutia. Dokl. Akad. Nauk SSSR, 320: 217-221 (in Russian).

Kopylova, M.G., Gurney, J.J. and Daniels, L.R.M., 1997. Mineral inclusions in diamonds from the River Ranch kimberlite, Zimbabwe. Contrib. Mineral. Petrol., 129: 366-384.

Kopylova, M.G., Russell, J.K. and Cookenboo, H., 1999. Petrology of peridotite and pyroxenite xenoliths from the Jericho kimberlite: Implications for the thermal state of the mantle beneath the Slave craton, Northern Canada. J. Petrol., 40: 79-104.

Luth, R.W., 1993. Diamonds, eclogites, and the oxidation state of the Earth's mantle. Science, 261: 66-68.

Luth, R.W., Virgo, D., Boyd, F.R. and Wood, B.J., 1990. Ferric iron in mantle-derived garnets. Implications for thermobarometry and for the oxidation state of the mantle. Contrib. Mineral. Petrol., 104: 56-72.

McCammon, C., Chinn, I., Gurney, J. and McCallum, M., 1998. Ferric iron content of mineral inclusions in diamonds from George Creek, Colorado determined using Mössbauer spectroscopy. Contrib. Mineral. Petrol., 133: 30-37.

McCammon, C.A., Griffin, W.L., Shee, S.H. and O'Neill, H.S.C., 2001. Oxidation during metasomatism in ultramafic xenoliths from the Wesselton kimberlite,
South Africa: Implications for the survival of diamond. Contrib. Mineral. Petrol., 141: 287-296.

Navon, O., 1999. Diamond formation in the Earth's mantle. In: J.J. Gurney, J.L. Gurney, M.D. Pascoe and S.H. Richardson (Editors), The P.H. Nixon Volume, Proc. VII International Kimberlite Conference. Red Roof Design, Cape Town, pp. 584-604.

O'Neill, H.S.C. et al., 1993. Ferric iron in the upper mantle and in transition zone assemblages: Implications for relative oxygen fugacities in the mantle. In: $T$. Takahashi, R. Jeanloz and D.C. Rubie (Editors), Evolution of the Earth and Planets. American Geophysical Union, Washington D.C., pp. 73-88.

Parkinson, I.J. and Arculus, R.J., 1999. The redox state of subduction zones: Insights from arc-peridotites. Chem. Geol., 160: 409-423.

Simakov, S.K., 1998. Redox state of Earth's upper mantle peridotites under the ancient cratons and its connection with diamond genesis. Geochim. Cosmochim. Acta, 62: 1811-1820.

Simakov, S.K., 2002. Redox state of upper mantle eclogite formation. 18th General Meeting Inter. Mineral. Assoc. Abstract Volume, pp. 243-244.

Sobolev, N.V., Butkunov, A.J., Lavrentjev, Y.G. and Usova, L.V., 1976. New data on mineral compositions, connecting with diamonds of the kimberlite pipe "Mir" (Yakutia). Geol. Geofiz., 17: 3-15 (in Russian).

Sobolev, V.N., McCammon, C.A., Taylor, L.A., Snyder, G.A. and Sobolev, N.V., 1999. Precise Mössbauer milliprobe determination of ferric iron in rock-forming minerals and limitations of electron microprobe analysis. Amer. Mineral., 84: 78-85.

Woermann, E. and Rosenhauer, M., 1985. Fluid phases and the redox state of the Earth's mantle. Fortschr. Mineral., 63: 263-349.

Wood, B.J., Bryndzia, L.T. and Johnson, K.E., 1990. Mantle oxidation state and its relationship to tectonic environment and fluid speciation. Science, 248: 337345 .

Woodland, A.B. and Peltonen, P., 1999. Ferric iron contents of garnet and clinopyroxene and estimated oxygen fugacities of peridotite xenoliths from the Eastern Finland Kimberlite Province. In: J.J. Gurney, J.L. Gurney, M.D. Pascoe and S.H. Richardson (Editors), The P.H. Nixon Volume, Proc. VII International Kimberlite Conference. Red Roof Design, Cape Town, pp. 904-911.

Woodland, A.B., 2001. The oxygen fugacity of the Earth's mantle: Variations with depth, Eleventh Annual V.M. Goldschmidt Conference. LPI Contribution No. 1088, Lunar and Planetary Institute, Houston, Abstract \#3148 (CD-ROM).

Contact: CA McCammon, Bayerisches Geoinstitut, Universität Bayreuth, D-95440 Bayreuth, Germany, E-mail: catherine.mccammon@uni-bayreuth.de 